\title{
STUDI PENGARUH PENGUATAN MEDAN TERHADAP TEGANGAN KELUARAN GENERATOR SINKRON SATU PHASA
}

\author{
Rizki Ellony Pratama ${ }^{1}$, Atmam $^{2}$, Usaha Situmeang ${ }^{3}$ \\ Program Studi Teknik Elektro, Fakultas Teknik, Universitas Lancang Kuning \\ Jl. Yos Sudarso Km. 8 Rumbai, Pekanbaru, Telp. (0761) 52324 \\ Email : rizkiellonypratama95@gmail.com,atmam@unilak.ac.id, usahasitumeang@unilak.ac.id
}

\begin{abstract}
ABSTRAK
Generator adalah suatu alat yang berfungsi mengubah energi mekanik menjadi listrik. Dibagian generator terdapat kumparan medan di rotor sehingga diberi penguatan. Pada saat diberi arus penguatan maka mengalir arus medan pada kumparan rotor dan menimbulkan fluksi medan magnet yang dihasilkan oleh kumparan stator. Sehingga tegangan induksi dan tegangan output generator yang dihasilkan oleh kumparan stator menjadi naik. Tujuan penelitian ini adalah membahas sistem penguatan medan pada arus dan tegangan generator sinkron satu phasa dan perbandingan tegangan output generator sinkron dengan beban resistif dan induktif. Dari hasil penelitian generator sinkron satu phasa tanpa beban dengan tegangan medan 22,46 Volt dan arus medan 0,90 Amper diperoleh tegangan keluaran generator sebesar 220 Volt dan saat tegangan medan 9,15 Volt dan arus medan 0,32 Amper diperoleh tegangan keluaran generator sebesar 100 Volt. Selanjutnya generator berbeban resistif dengan arus medan 1,08 Amper diperoleh tegangan output generator sebesar 220 Volt, arus medan 0,39 Amper tegangan output generator 100 Volt selanjutnya generator beban induktif dengan arus medan 1,13 Amper tegangan output sebesar 220 Volt, Arus medan 0,43 Amper tegangan output 100 Volt.
\end{abstract}

Kata kunci : Generator Sinkron Satu Phasa, Penguatan, Tegangan

\begin{abstract}
A generator is a device that functions to generate power from mechanical energy. A generator has an armature on the rotor which is then given excitation. When being in excitation, the field current flows within the armature and generates magnetic field flux produced by stator coil. Then, it results in increase in induction voltage and output voltage of the generator resulted from stator coil. The research aims to define the excitation system of current and voltage of a single-phase synchronous generator and to compare output voltage the synchronous generator with resistive and inductive load. The result shows that in the single-phase synchronous generator without load, with field voltage of 22.46 Volt and field current of $0.90 \mathrm{Amp}$, the output voltage measured was 220 Volt, and while field voltage was 9.15 Volt with field current of 0.32 Amp, the generator output voltage was 100 Volt. In addition, in the generator with resistive load with field current of 1.08 Amps, the output field measured was 220 Volt, with 0.39 Amp of field current and 100 Volt output voltage, while the generator with inductive load with 1.13 Amps of field current and 220 Volt output voltage and 0.43 Amp of field current, the output voltage recorded was 100 Volt.
\end{abstract}

Keywords : Single-phase Synchronous Generator, Excitation, and Voltage.

\section{PENDAHULUAN}

Generator adalah suatu perangkat yang berfungsi untuk mengubah energi mekanik menjadi energi listrik. Generator sinkron memiliki kumparan medan yang terletak pada bagian rotor dan kumparan jangkar pada stator. Kumparan medan yang terdapat pada rotor generator sinkron diberi penguatan. Penguatan dalam generator sangat penting karena terbangkitnya tegangan yang disebabkan sistem penguatan itu sendiri. Besarnya tegangan yang dibangkitkan oleh generator tergantung pada besarnya arus penguatan dan kecepatan medan magnet yang memotong belitan jangkar generator setelah dihubungkan ke beban. Setelah dihubungkan ke beban maka tegangan yang ada digenerator akan berubah. Hal ini disebabkan dalam belitan jangkar mengalir arus yang melawan medan rotor disebut reaksi jangkar. 
Generator sinkron membutuhkan sistem penguatan medan yang berfungsi mengendalikan tegangan, arus dan daya output generator. Dengan mengatur output generator diperlukan suatu alat regulasi tegangan selanjutnya disearahkan terlebih dahulu terhadap kumparan medan menggunakan recitifier. Sehingga dapat mengatur besar atau kecilnya tegangan keluaran agar tetap konstan walaupun kondisi beban yang berubah-ubah.

Pada generator sinkron satu phasa ini dapat dilakukan berbagai macam penelitian salah satunya pengaruh penguatan medan terhadap tegangan keluaran generator satu phasa. Dengan berubahnya tegangan penguatan maka berubah tegangan keluaran generator sinkron satu phasa. Untuk itu perlu dilakukan pengujian berupa analisis tegangan terminal, tegangan regulator, arus regulator, tegangan medan beserta arus medan generator sinkron satu phasa.

\section{METODE PENELITIAN}

\section{Pembuatan Wiring Diagram}

Sistem kerja generator sinkron satu phasa yang digerakan oleh penggerak mula (Prime mover) yang sudah terkopel dengan generator.Untuk menghasilkan tegangan output dari generator sinkron diperlukan penguatan medan DC, dimana tegangan DC diperlukan sebuah rangkaian rectifier (penyearah) yang diteruskan ke belitan eksitasi. Pada saat diberi penguatan maka mengalir arus medan $\left(\mathrm{I}_{\mathrm{f}}\right)$ pada kumparan rotor dan menaikkan fluksi medan magnet $(\phi)$ yang dihasilkan oleh kumparan stator. Maka tegangan induksi (E) yang dihasilkan oleh kumparan stator menjadi naik dan tegangan output $\left(\mathrm{V}_{\mathrm{t}}\right)$ pun juga ikut naik. Sebuah wiring diagram generator sinkron satu phasa seperti pada Gambar 1 :

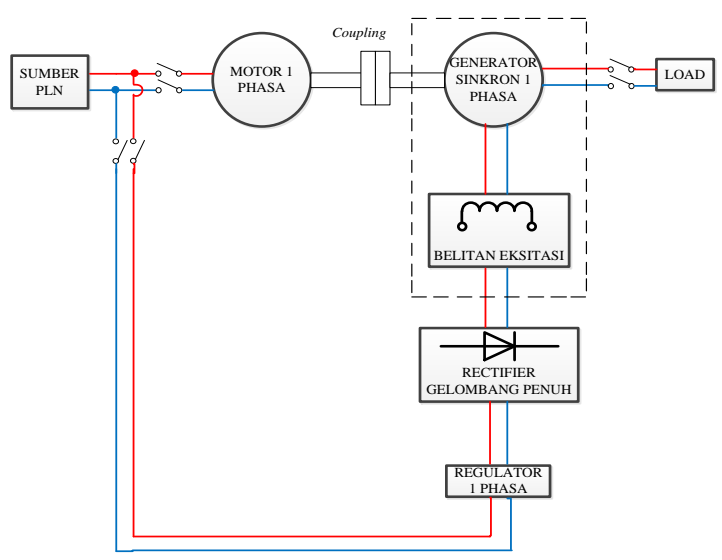

Gambar 1. Wiring Diagram Generator Sinkron Satu Phasa

\section{Generator Sinkron}

Generator adalah suatu sistem yang menghasilkan tenaga listrik dengan masukan tenaga mekanik. Jadi disini generator berfungsi untuk mengubah tenaga mekanik menjadi tenaga listrik yang mempunyai prinsip kerja, bilamana rotor diputar maka belitan kawatnya akan memotong gaya-gaya magnet pada kutub magnet, sehingga terjadi perbedaan tegangan, dengan dasar inilah timbul arus listrik, arus melalui kabel atau kawat yang kedua ujungnya dihubungkan dengan cincin geser [1]

Generator sinkron banyak dipergunakan pada pembangkit tenaga listrik. Sebagaimana pada generator arus searah, belitan (kumparan) jangkar ditempatkan pada jangkar rotor sedangkan belitan medan ditempatkan pada stator, demikian pula untuk generator sinkton dengan kapasitas kecil. Akan tetapi pada generator sinkron yang dipergunakan untuk pembangkit dengan kapasitas besar, belitan atau kumparan jangkar ditempatkan pada stator, sedangkan belitan medan ditempatkan pada rotor [2].

Didalam generator sinkron terdiri dari lilitan jangkar dan medan magnet tetapi ada satu perbedaan. Dimana seperti pada generator DC, jangkar berputar dan medan magnet tetap. Pengaturan pada generator sinkron adalah kebalikannya dari generator DC, karena dalam hal ini konstruksinya berupa standar yang terdiri dari lilitan jangkar yang dipasang pada elemen yang tetap dan disebut stator dan belitan medan pada elemen berputar yang disebut rotor [3].

Generator sinkron memiliki beberapa keunggulan, termasuk struktur rotor sederhana dan efisiensi tinggi. Namun, pada generator ini, nilai pengaturan tegangan sangat meningkat pada kondisi beban berlebih karena medan magnet tidak dapat dikontrol [4].

Pada generator terdapat lilitan stator adalah menyediakan daya penguatan untuk generator. Penguatan yang diberikan dapat saja berubah atau tidak tetap [5].

\section{Konstruksi Generator Sinkron}

Dalam generator sinkron, medan magnet rotor dihasilkan baik dengan merancang rotor sebagai magnet permanen atau dengan menerapkan arus searah ke rotor berlaku buat elektromagnet. Rotor generator kemudian dihidupkan oleh penggerak utama, menghasilkan medan magnet berputar di dalam mesin. Medan magnet berputar ini menginduksi set tegangan di dalam gulungan stator generator [6].

Sama halnya dengan mesin induksi, mesin sinkron terdiri atas stator dan rotor. Adapun bentuk kumparan statornya sama dengan kumparan stator 
pada mesin induksi. Begitu pula dengan banyaknya lapisan kumparan didalam jalur/alur rangka statornya (single layer dan double layer) serta hubungan kumparan 3 phasanya (bintang dan segitiga), namun macamnya kumparan medannya pada rotor berdasarkan bentuknya berbeda. Pada mesin sinkron ada dua macam yaitu berbentuk kutub sepatu dan berbentuk celah udara sama rata (silinder atau kadang disebut sebagai non silent) [7].

Sehingga dalam konstruksi generator sinkron terdiri stator, rotor dan celah udara. Pada stator adalah bagian dari mesin yang diam dan berbentuk silinder. Sedangkan rotor adalah bagian dari mesin yang berputar dan juga berbentuk silinder dan untuk celah udara adalah bagian ruangan antara stator dan rotor. Konstruksi generator sinkron seperti pada Gambar 2 [2].

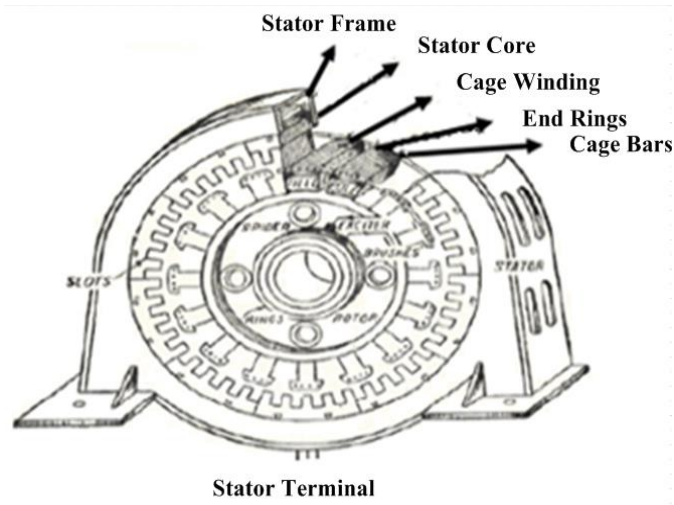

Gambar 2. Konstruksi Generator Sinkron

\section{Prinsip Kerja Motor Induksi Tiga Phasa}

Prinsip kerja generator sinkron bendasarkan induksi elektromagnetis. Setelah rotor diputar oleh penggerak mula (prime mover), dengan demikian kutub-kutub yang ada pada rotor akan berputar. Jika kumparan kutub diberi arus searah maka pada permukaan kutub akan timbul medan magnet (garisgaris gaya fluks) yang berputar, kecepatannya sama dengan putaran kutub. Garis-garis gaya fluks yang berputar tersebut akan memotong kumparan jangkar yang ada distator sehingga pada kumparan jangkar tersebut timbul GGL atau tegangan induksi [2].

Kumparan medan yang terdapat pada rotor dihubungkan dengan sumber eksitasi yang akan disuplai oleh arus searah sehingga menimbulkan fluks yang besarnya tetap terhadap waktu. Kemudian penggerak mula (primemover) yang sudah terkopel dengan rotor segera dioperasikan sehingga rotor akan berputar pada kecepatan nominalnya [8].

$$
n=\frac{120 \times f}{p}
$$

Keterangan:

$n=$ Kecepatan putar rotor (rpm)

$p=$ Jumlah kutub rotor

$f=$ Frekuensi $(\mathrm{Hz})$

\section{Generator Tanpa Beban}

Pada generator tanpa beban ini adalah dengan mengatur generator pada kecepatan nominal, dimana terminalnya tidak dibebani serta menyetel arus medannya hingga nol. Setelah itu akan terlihat arus medan meningkat secara bertahap, pada saat yang bersamaan timbul tegangan induksi pada kumparan jangkar stator generator yang juga semakin meningkat. Dimana arus medan $\left(\mathrm{I}_{\mathrm{f}}\right)$ sebanding dengan fluks $(\phi)$ yang timbul. Peningkatan arus medan dan tegangan induksi tersebut dicatat secara bersamaan untuk melihat hubungan keduanya. Pada saat tegangan terminal generator tidak dibebani, arus jangkar $I_{a}$ sama dengan nol. Sehingga tegangan terminalnya akan sama dengan GGLnya $\left(E_{a}\right)$.

Dengan memutar alternator pada kecepatan sinkron dan rotor diberi arus medan $\left(\mathrm{I}_{\mathrm{f}}\right)$, tegangan $\left(\mathrm{E}_{0}\right)$ akan terinduksi pada kumparan jangkar stator. Di dalam keadaan tanpa beban arus jangkar tidak mengalir pada stator. Karenanya tidak terdapat pengaruh reaksi jangkar. Fluks hanya dihasilkan oleh arus medan $\left(\mathrm{I}_{\mathrm{f}}\right)$ [8].

$$
\mathrm{E}_{\mathrm{a}}=\mathrm{c} \times \mathrm{n} \phi
$$

Keterangan :

c $=$ Konstanta mesin

$\mathrm{n}=$ Putaran Sinkron

$\phi=$ Fluks yang dihasilkan $\mathrm{I}_{\mathrm{f}}$

\section{Analisa Rangkaian Generator Sinkron}

Dengan Memutar generator sinkron (rpm) pada kecepatan sinkron dan diberi arus medan, maka tegangan akan terinduksi pada kumparan stator. Karena alasan itulah generator ini disebut generator sinkron atau bisa disebut juga dengan Alternator [8].

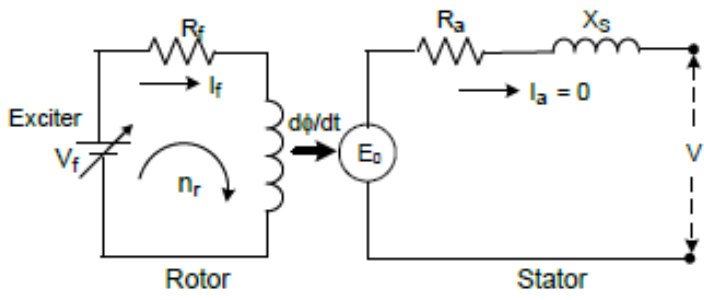

Gambar 3. Rangkaian Ekivalen Generator Tanpa Beban

Dalam keadaan tanpa beban arus jangkar tidak mengalir pada stator, karenanya tidak terdapat 
pengaruh reaksi jangkar. Fluks hanya dihasilkan oleh arus medan. Apabila arus medan diubah-ubah harganya, akan diperoleh tegangan seperti pada Gambar 3 .

Bentuk kurva pemagnetan seperti pada Gambar 4 [8].

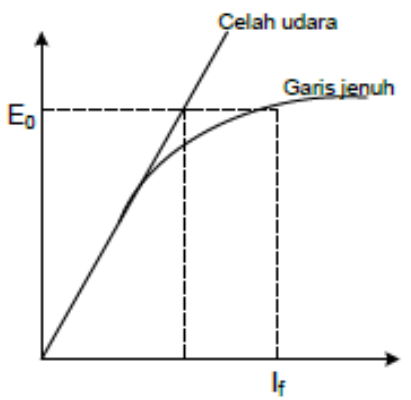

Gambar 4. Kurva Pemagnetan

Dan untuk mendapatkan arus medan pada kumparan rotor adalah [6] :

$$
I_{f}=\frac{V_{f}}{R_{f}}
$$

Keterangan :

$\mathrm{I}_{f} \quad=$ Arus eksitasi (Amper)

$\mathrm{V}_{f} \quad=$ Tegangan eksitasi (Volt)

$\mathrm{R}_{f} \quad=$ Tahanan kumparan Rotor (Ohm)

Tegangan induksi yang dihasilkan pada kumparan stator adalah [6] :

$$
E=K_{f} \times I_{f}
$$

Keterangan :

$\mathrm{K}_{f}=$ Konstanta kumparan rotor

$\mathrm{I}_{f}=$ Arus eksitasi (Amper)

\section{Generator Sinkron Berbeban}

Pada generator sinkron berbeban menampilkan rangkaian ekivalen seperti pada Gambar 5.

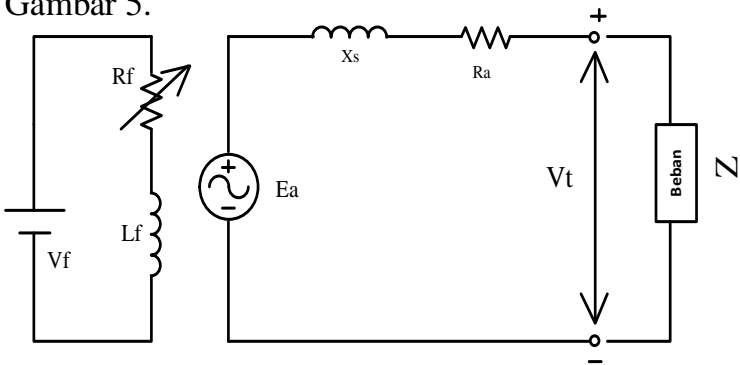

Gambar 5. Rangkaian Ekivalen Generator Sinkron Berbeban
Disaat berbeban nilai $\mathrm{E}_{\mathrm{a}}$ tidak sama dengan tegangan terminal karena terjadi reaksi jangkar. Reaksi jangkar disebabkan oleh arus beban yang mengalir pada kumparan jangkar. Maka untuk generator sinkron berbeban adalah [2].

$$
E=V_{T}+I_{L} \times Z
$$

Keterangan :

$V_{T}=$ Tegangan Terminal (Volt)

$I_{L}=$ Arus Beban (Amper)

$\mathrm{Z}=$ Impedansi $(\mathrm{Ohm})$

\section{Rectifier Satu Phasa}

Ada dua jenis rectifier satu phasa yang mengkonversikan suplay AC satu phasa menjadi tegangan DC yaitu penyearah setengah gelombang satu phasa dan penyearah gelombang penuh satu phasa. Dioda yang dianggap ideal adalah memiliki nol tegangan maju dan mundur waktu pemulihan. Asumsi ini umumnya berlaku untuk kasus penyearah dioda yang digunakan pada frekuensi rendah, sebagai input, dan penurunan tegangan kecil dibandingkan dengan tegangan puncak dari listrik. Selanjutnya, diasumsikan bahwa bebannya murni resistif sehingga beban tegangan dan arus beban memiliki kesamaan bentuk gelombang [9].

\section{Penyearah Gelombang Penuh (Rectifier Full Wave)}

Rectifier gelombang penuh dengan model tak terkontrol menggunakan 2 atau 4 dioda. Rectifier model ini biasanya cukup banyak digunakan pada umumnya. Hampir rata-rata alat elektronik menggunakan alat tersebut. Rectifier dengan 4 buah dioda ditampilkan seperti pada Gambar 6 [10].

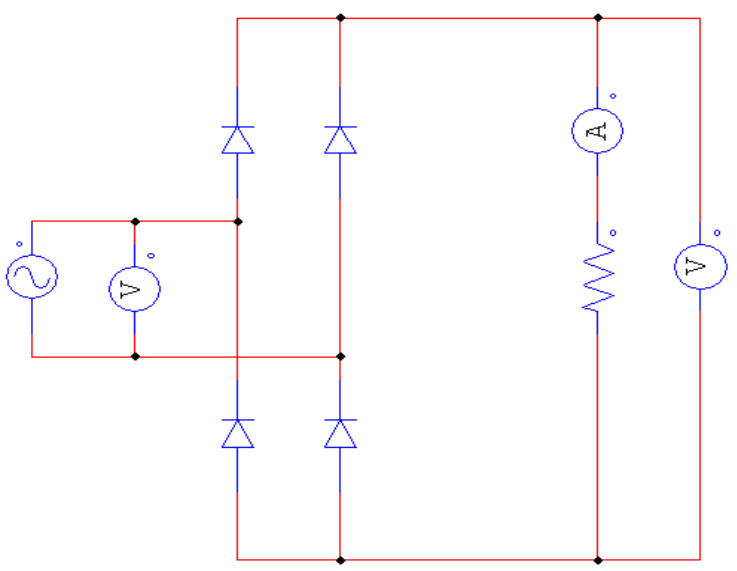

Gambar 6. Rangkaian Full Wave Rectifier

Dengan sifat dioda yang berupa konduksi, bila mengalami konduksi maka kondisi nya akan maju 
(sehingga arusnya mengalir searah) dan akan padam bila arus yang melewati dibawah batas minimum. Dengan demikian 4 dioda akan bekerja secara otomatis tanpa ada kontrol dari luar. Bentuk gelombang tegangan sumber dan tegangan output rectifier seperti pada Gambar 7 [10].
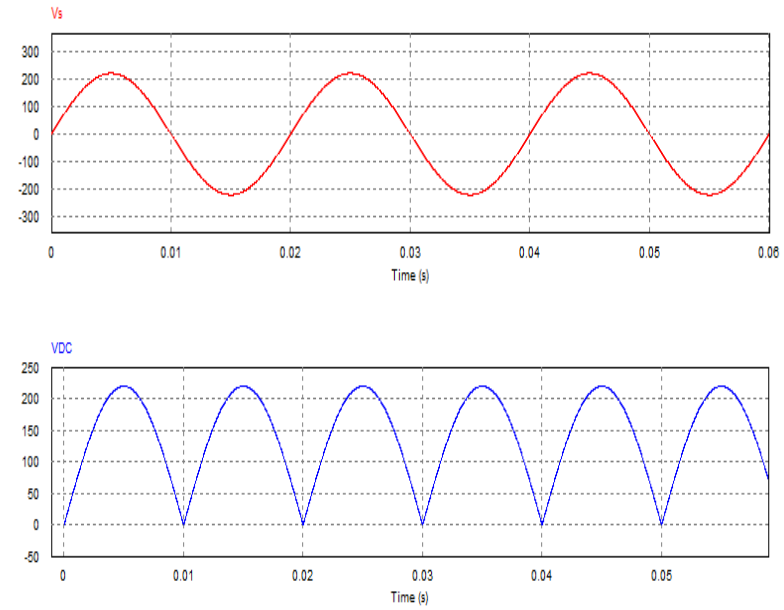

Gambar 7. Bentuk Gelombang Tegangan Sumber dan Tegangan Output Full Wave Rectifier

Metoda integrasi yang sama baik digunakan pada sistem setengah gelombang, karena dapat dihitung nilai arus rata-rata dan tegangan output pada rectifier. Sedangkan pada rectifier gelombang penuh batas integrasi pada sudut $0^{0}$ hingga $180^{\circ}$ dan itu diulangi 2 kali untuk satu siklus gelombang. Persamaan untuk mendapatkan nilai tegangan ratarata $\left(\mathrm{V}_{\mathrm{dc} \text {-avg }}\right)$ gelombang penuh sebagai berikut [10]

$$
\mathrm{V}_{\text {DC RATA-RATA }}=\frac{2 \times \mathrm{V}_{\mathrm{m}}}{\pi}
$$

Besar nilai tegangan $\left(\mathrm{V}_{\mathrm{dc}-\mathrm{rms}}\right)$ pada recitifier gelombang penuh adalah [10] :

$$
\mathrm{V}_{\mathrm{dc}-\mathrm{rms}}=\frac{\mathrm{V}_{\mathrm{m}}}{\sqrt{2}}
$$

Nilai tegangan maximum $\left(\mathrm{V}_{\mathrm{m}}\right)$ adalah $[10]$ :

$$
\mathrm{V}_{\mathrm{m}}=V_{S} \times \sqrt{2}
$$

\section{HASIL DAN PEMBAHASAN}

\section{Kecepatan Putaran Generator Sinkron Satu} Phasa

Untuk mendapatkan kecepatan generator sinkron satu phasa digunakan persamaan (1) sebagai berikut:

$$
n=\frac{120 \times 50}{4}=\frac{6000}{4}=1500 \mathrm{rpm}
$$

\section{Parameter Generator Sinkron Satu Phasa Tanpa} Beban

Nilai tegangan $\mathrm{DC}_{\text {rata-rata }}\left(\mathrm{V}_{\text {DC-Rata-Rata }}\right)$ dan tegangan DC Root Mean Squared ( $\mathrm{V}_{\mathrm{DC}-\mathrm{RMS}}$ ) dihitung dengan persamaan (7) dan (8) sebagai berikut :

Tegangan DC rata-rata

$$
\begin{aligned}
& \mathrm{V}_{\mathrm{s}}=24,96 \text { Volt } \\
& \begin{aligned}
\mathrm{V}_{\mathrm{m}} & =V_{s} \times \sqrt{2} \\
& =24,96 \times \sqrt{2} \\
& =35,29 \text { Volt }
\end{aligned} \\
& \mathrm{V}_{\mathrm{DC}-\mathrm{AVG}}=\frac{2 \times \mathrm{V}_{\mathrm{m}}}{\pi} \\
& =\frac{2 \times 35,29}{\pi} \\
& =22,46 \text { Volt }
\end{aligned}
$$

Tegangan DC rms

$$
\begin{aligned}
\mathrm{V}_{\mathrm{DC} \text { RMS }} & =\frac{\mathrm{V}_{\mathrm{m}}}{\sqrt{2}} \\
& =\frac{35,29}{\sqrt{2}} \\
& =24,95 \text { Volt }
\end{aligned}
$$

Maka nilai arus medan dari generator tanpa beban menggunakan persamaan (3) sebagai berikut :

$$
\begin{aligned}
\mathrm{I}_{f} & =\frac{V_{f}}{R_{f}} \\
& =\frac{20,87}{23,12} \\
& =0,90 \text { Amper }
\end{aligned}
$$

Nilai konstanta dari generator sinkron satu phasa tanpa beban menggunakan persamaan (2) maka :

$$
\begin{aligned}
c & =\frac{E_{a}}{N \times \phi} \\
& =\frac{220}{1500 \times 1,01} \\
& =0,145
\end{aligned}
$$




\section{Parameter Generator Sinkron Satu Phasa Berbeban Resistif}

Nilai tegangan $\mathrm{DC}_{\text {rata-rata }}\left(\mathrm{V}_{\text {DC-Rata-Rata }}\right)$ dan tegangan DC Root Mean Squared ( $\mathrm{V}_{\mathrm{DC}-\mathrm{RMS}}$ ) dihitung dengan persamaan (7) dan (8) sebagai berikut :

Tegangan DC rata-rata

$$
\begin{aligned}
& \mathrm{V}_{\mathrm{s}}=29,66 \text { Volt } \\
& \mathrm{V}_{\mathrm{m}}=V_{\mathrm{s}} \times \sqrt{2} \\
& =29,66 \times \sqrt{2} \\
& =41,94 \text { Volt } \\
& \mathrm{V}_{\mathrm{DC}-\mathrm{AVG}}=\frac{2 \times \mathrm{V}_{\mathrm{m}}}{\pi} \\
& =\frac{2 \times 41,94}{\pi} \\
& =26,69 \text { Volt }
\end{aligned}
$$

Tegangan DC rms

$$
\begin{aligned}
\mathrm{V}_{\mathrm{DC} \text { RMS }} & =\frac{\mathrm{V}_{\mathrm{m}}}{\sqrt{2}} \\
& =\frac{41,94}{\sqrt{2}} \\
& =29,65 \text { Volt }
\end{aligned}
$$

Maka nilai arus medan dari generator tanpa beban menggunakan persamaan (3) sebagai berikut :

$$
\begin{aligned}
\mathrm{I}_{f} & =\frac{V_{f}}{R_{f}} \\
& =\frac{25,17}{23,12} \\
& =1,08 \text { Amper }
\end{aligned}
$$

Berdasarkan data penelitian, maka dilakukan perhitungan tegangan output generator sinkron satu phasa pada saat berbeban resistif sebagai berikut :

\section{Reaktansi Stator :}

$$
\begin{aligned}
X_{S} & =2 \pi \times f \times L \\
& =2 \pi \times 50 \times 0,03079 \\
& =9,672
\end{aligned}
$$

$$
\begin{aligned}
Z & =\sqrt{R^{2}+X^{2}} \\
& =\sqrt{5^{2}+9,672^{2}} \\
& =\sqrt{25+93,547} \\
& =\sqrt{118,547} \\
& =10,887 \Omega
\end{aligned}
$$

Maka nilai tegangan induksi yang dihasilkan oleh kumparan stator dapat menggunakan persamaan (5) maka :

$$
\begin{aligned}
E & =V_{T}+I_{L} \times Z \\
& =220+2,20 \times 10,887 \\
& =243,951 \text { Volt }
\end{aligned}
$$

\section{Parameter Generator Sinkron Satu Phasa Berbeban Induktif}

Nilai tegangan $\mathrm{DC}_{\text {rata-rata }}\left(\mathrm{V}_{\text {DC-Rata-Rata }}\right)$ dan tegangan DC Root Mean Squared ( $\mathrm{V}_{\mathrm{DC}-\mathrm{RMS}}$ ) dihitung dengan persamaan (7) dan (8) sebagai berikut :

$$
\begin{aligned}
& \text { Tegangan DC rata-rata } \\
& \mathrm{V}_{\mathrm{s}}=29,90 \text { Volt } \\
& \mathrm{V}_{\mathrm{m}}=V_{\mathrm{s}} \times \sqrt{2} \\
& =29,90 \times \sqrt{2} \\
& =42,28 \text { Volt } \\
& \begin{aligned}
\mathrm{V}_{\mathrm{DC}-\mathrm{AVG}} & =\frac{2 \times \mathrm{V}_{\mathrm{m}}}{\pi} \\
& =\frac{2 \times 42,28}{\pi} \\
& =26,91 \text { Volt }
\end{aligned}
\end{aligned}
$$

Tegangan DC rms

$$
\begin{aligned}
\mathrm{V}_{\mathrm{DC} \text { RMS }} & =\frac{\mathrm{V}_{\mathrm{m}}}{\sqrt{2}} \\
& =\frac{42,28}{\sqrt{2}} \\
& =29,89 \text { Volt }
\end{aligned}
$$

Maka nilai arus medan dari generator tanpa beban menggunakan persamaan (3) sebagai berikut :

$$
\begin{aligned}
\mathrm{I}_{f} & =\frac{V_{f}}{R_{f}} \\
& =\frac{26,16}{23,12} \\
& =1,13 \text { Amper }
\end{aligned}
$$

Berdasarkan data penelitian, maka dilakukan perhitungan tegangan output generator sinkron satu phasa pada saat berbeban resistif sebagai berikut :

$$
\begin{aligned}
E & =V_{T}+I_{L} \times Z \\
& =220+1,04 \times 10,887 \\
& =220+11,322 \\
& =231,322 \text { Volt }
\end{aligned}
$$


SainETIn (Jurnal Sain, Energi, Teknologi \& Industri), Vol. 3 No. 2, Juni 2019, pp. 69 - 76

ISSN 2548-6888 print, ISSN 2548-9445 online

Tabel 1. Hasil Perhitungan tegangan dan arus medan saat tanpa beban dan beberbeban resistif dan induktif

\begin{tabular}{cccc}
\hline Perhitungan & Tanpa Beban & Beban Resistif $(\mathrm{R})$ & Beban Induktif $(\mathrm{L})$ \\
\hline & 22.46 & 26.69 & 26,91 \\
& 18,96 & 22,28 & 21,46 \\
Tegangan Medan & 16,10 & 19,04 & 18,16 \\
$\left(\mathrm{~V}_{\mathrm{dc}}\right)$ & 14,21 & 16,60 & 14,96 \\
& 12,15 & 14,40 & 12,76 \\
& 10,77 & 12,42 & 10,09 \\
& 9,15 & 10,85 & 9,11 \\
\hline & 0,90 & 1,08 & 1,13 \\
Arus Medan & 0,75 & 0,89 & 0,91 \\
(Idc) & 0,63 & 0,75 & 0,78 \\
& 0,55 & 0,65 & 0,69 \\
& 0,46 & 0,55 & 0,58 \\
& 0,40 & 0,43 & 0,48 \\
Tegangan Induksi & 0,32 & 0,39 & 0,43 \\
(E) & 220 & 243,951 & 231,322 \\
& 200 & 221,665 & 207,620 \\
& 180 & 199,487 & 185,987 \\
& 160 & 177,419 & 164,681
\end{tabular}

Bentuk grafik generator sinkron satu phasa tanpa beban pada arus medan terhadap tegangan terminal dengan data Tabel 1 digambarkan dengan grafik seperti Gambar 8.

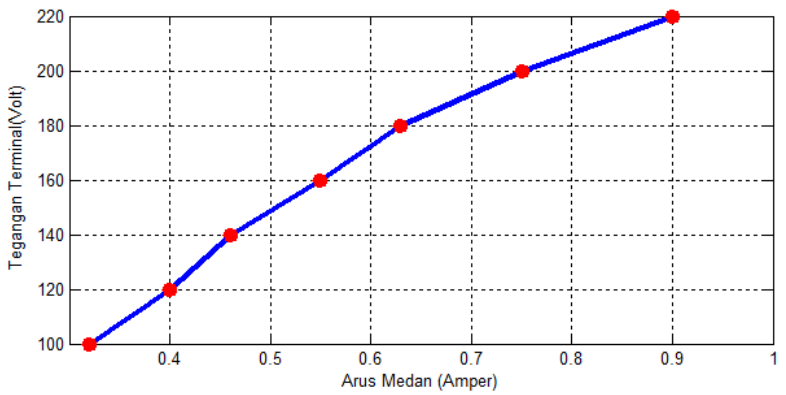

Gambar 8. Grafik Perubahan Arus Medan Terhadap Tegangan Terminal Generator Sinkron Satu Phasa Tanpa Beban

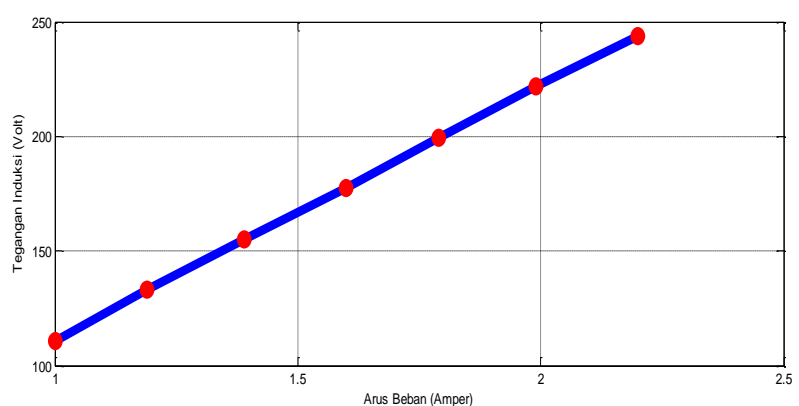

Gambar 9. Grafik Perubahan Arus Beban Terhadap Tegangan Induksi Generator Sinkron Satu Phasa Berbeban Resistif
Bentuk grafik generator sinkron satu phasa berbeban resistif pada arus beban terhadap tegangan induksi dengan data Tabel 1 digambarkan dengan grafik seperti pada Gambar 9.

Selanjutnya bentuk grafik generator sinkron satu phasa berbeban induktif pada arus beban terhadap tegangan terminal digambarkan dengan grafik seperti pada Gambar 8

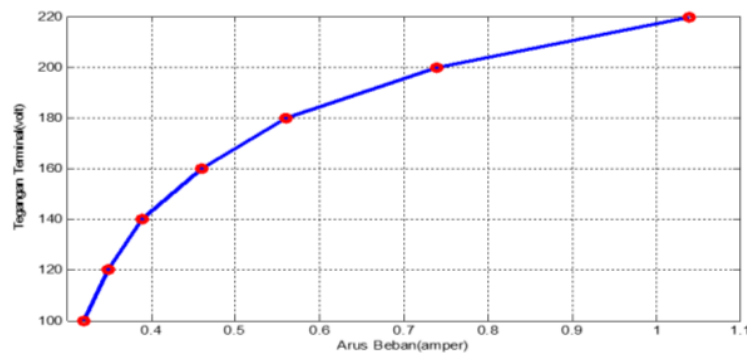

Gambar 8. Grafik Perubahan Arus Medan Terhadap Tegangan Terminal Generator Sinkron Satu Phasa Berbeban Induktif

\section{KESIMPULAN}

Berdasarkan hasil perhitungan yang dilakukan, maka dapat dibuat beberapa kesimpulan sebagai berikut :

1. Dari hasil perhitungan generator sinkron satu phasa tanpa beban pada saat tegangan medan 22,46 Volt dan arus medan 0,90 Amper diperoleh tegangan keluaran generator sebesar 220 volt dan saat tegangan medan 9,15 Volt dan 
arus medan 0,32 Amper diperoleh tegangan keluaran generator sebesar 100 Volt.

2. Dari hasil perhitungan generator sinkron satu phasa berbeban resistif dengan arus medan 1,08 Amper diperoleh tegangan output generator sebesar 220 Volt, Arus medan 0,39 Amper tegangan output generator 100 Volt. Dan generator beban induktif dengan arus medan 1,13 Amper tegangan output sebesar 220 volt, arus medan 0,43 Amper tegangan output 100 Volt.

3. Dari hasil pengukuran generator sinkron satu phasa tanpa beban pada saat tegangan input rectifier 24,96 Volt diperoleh tegangan output generator sebesar 220 Volt dan tegangan output rectifier 22,46 Volt diperoleh tegangan output generator sebesar 220 Volt.

\section{DAFTAR PUSTAKA}

[1] Daryanto, 2016, Elektronika Kelistrikan, Bandung: Alfabeta. Retrieved from www.cvalabeta.com

[2] Hamzah Berahim. 1994, Teknik Tenaga Listrik (Kedua). Yogyakarta: Andi Offset
[3] Theraja, A.K \& Theraja, B. L.. 2002, Electrical Technology Volume II AC \&DC Machines. New Delhi.

[4] Naoe, N. 2008, Self Excitation Characteristic of a hybrid excitation single phase synchronous generator, International Conference on Electrical Machines, 1-4, Portugal.

[5] Armansyah, S. 2016, Pengaruh Penguatan Medan Generator Sinkron Terhadap Tegangan Terminal, Journal of Electrical Technolgy, ISSN 2502-3624, Vol. 1, No. 3, Medan.

[6] Chapman, Stephen J., 2005, Electric Machinery Fundamental, Fourt Edition, McGraw-Hill Companies, Inc., New York

[7] Mochtar Wijaya. 2001, Dasar Dasar Mesin Listrik. Jakarta: Djambatan.

[8] Zuhal. 2000, Dasar Teknik Tenaga Listrik dan Elektronika Daya. Jakarta: Gramedia Pustaka Utama.

[9] Rashid. 2001, Power Electronics Academic Press Series in Engineering

[10] Ashari, M. 2017, Dasar Konverter Elektronika Daya (Pertama). Bandung : Informatika. 